\title{
"The Modern Way to Loveliness": Middle-Class Cosmetics and Chain-Store Beauty Culture in Mid-Twentieth-Century Britain
}

9,788 words

\begin{abstract}
Forthcoming in 'Women's History Review'. This is the final accepted, pre-proof version of the article. Its seven images have not been reproduced here for copyright issues. Please only cite the final published version.
\end{abstract}

Author: Richard Hornsey, University of Nottingham

\begin{abstract}
:
In May 1935, the British manufacturer Boots launched 'Number Seven', a premium range of skin-care products sold via its nationwide network of chain-store chemists. Using material from the Boots Archive, this paper traces the early history of Number Seven to explore the changing meanings of middle-class cosmetics across the mid-twentieth century. Number Seven offered provincial and suburban women an explicitly modern form of facial beauty that married the logics of mass production to traditional moral aesthetics. Through the discourse of 'loveliness' and the careful management of in-store experience, it negotiated the prerogative connotations of colour cosmetics and the problematic influence of cinematic glamour. Yet by the mid-1950s, this construction had been superseded by a more situational understanding of beauty that was dependent on context and the appreciation of others. This fundamental shift in the normative aesthetics of public femininity had important implications for women on both sides of Boots' toilet counters. (151 words)
\end{abstract}

\section{Bio details:}

Richard Hornsey is Lecturer in Modern British History at the University of Nottingham. He is the author of The Spiv and the Architect: Unruly Life in Postwar London (University of Minnesota Press, 2010). Correspondence to: Dr Richard Hornsey, Lenton Grove, University of Nottingham, University Park, Nottingham, NG7 2RD. Email: richard.hornsey@nottingham.ac.uk 


\section{Text of Article:}

She entered the branch of "Boots The Chemists" with a timid air - the middleaged woman dressed in sombre attire and quite 'un-made-up' compared with many modern faces.

Approaching the Toilet counter [...] she bent confidentially towards the assistant and whispered, "I want to buy something I have never bought before. My husband does not approve of it - it's lipstick, Miss - you know my sister-inlaw from London always uses it and yet you cannot detect it. Now I am going to a wedding, and I know they will all be 'lip-sticked' and I don't want to feel out of it, so have you got something which can't be detected?" [...]

The assistant immediately brought out an array of lipsticks and, quoting the prices of Reponse and Grekis, handed same to the lady; but the latter hastily murmured, "Oh, my sister-in-law pays much more than that, something about $4 / 6 . "[\ldots]$

After a long and studied survey, broken now and again with details of her home life, she decided that KISSPROOF - at 6d. - was the very thing she required, and handing over her small piece of silver in exchange for the bright little stick she departed on her way. ${ }^{1}$

The above encounter took place in 1931 in the Boots store in Allenton, a suburb of Derby, and captures many women's ambivalent relationship to colour cosmetics in the early

${ }^{1}$ G. P. (July-Aug. 1931) This Business of Buying a Lipstick, The Bee, 10(8), p. 313. 
1930s. Whilst the use of make-up was now less daring than it had been in the 1920s, for many older, provincial or suburban women, the experience of buying or wearing a lipstick was still a fraught one. For some, a made-up face might invoke the flippant decadence of the post-war aristocracy as figured in the gossip columns of the Daily Mail, within the pages of 'amusing' Vogue, or in the character of Iris Storm in Michael Arlen's 1924 best-seller, The Green Hat. ${ }^{2}$ Yet by the turn of the 1930s, this was likely to have been superseded by a more proximate set of working-class associations. A new generation of young working women, freed from the drudgery of domestic service by the assembly line and shop work, had begun to forge a mode of public self-fashioning out of the cheap, mass-produced delights of Hollywood and colour cosmetics. Applying lipstick and rouge enabled them to express their own defiant modernity and explore a short-lived moment of freedom before the onset of marriage and motherhood. ${ }^{3}$

For some social commentators, made-up working girls visibly appeared dangerously enthralled to the synthetic pleasures of the American culture industry and were a troubling harbinger of social and national decline. ${ }^{4}$ Yet for British women of the 'new' middle classes, the

\footnotetext{
${ }^{2}$ D. J. Taylor (2008) Bright Young People: The Rise and Fall of a Generation, 1918-1940 (London: Vintage); Christopher Reed (2996) Design for (Queer) Living: Sexual Identity, Performance, and Décor in British Vogue, 1922-1926, GLQ: A Journal of Lesbian and Gay Studies, 12(3), pp. 377-403; Michael Arlen ([1924]/2008) The Green Hat (London: Capuchin).

${ }^{3}$ Sally Alexander (1999) Becoming a Woman in London in the 1920s and '30s, in Morag Shiach (Ed.) Feminism and Cultural Studies, (Oxford: Oxford University Press), pp. 200-227; Carol Dyhouse (2011) Glamour: Women, History, Feminism (London: Zed Books), pp. 78-84; Annette Kuhn (1996) Cinema Culture and Femininity in the 1930s, in Christine Gledhill and Gillian Swanson (Eds.) Nationalising Femininity: Culture, Sexuality and Cinema in World War Two (Manchester: Manchester University Press), pp, 177-192; Selina Todd (2005) Young Women, Work, and Leisure in Interwar England, The Historical Journal, 48(3), pp. 789-809. Matt Houlbrook (2007) has traced how London's working-class queans also exploited these dynamics: "The Man with the Powder Puff” in Interwar London, The Historical Journal, 50(1), pp. 145171.

${ }^{4}$ Alexander, 'Becoming a Woman', pp. 200-1; Mark Glancey (2006) Temporary American Citizens? British Audiences, Hollywood Films and the Threat of Americanization in the 1920s,
} 
threat could feel more personal. Many lower-middle-class housewives had recently left their impoverished inner-urban neighbourhoods for the comparative gentility of the suburbs, where they had begun to forge a precarious new identity built on a 'nice and neat' appearance, emotional dedication to home and family, and thrifty good sense at the shops. ${ }^{5}$ The use of colour cosmetics could imperil this construction by inviting readings of sexual excess, of budgetary self-indulgence, and of aspirations to a lifestyle more glamorous than that available at home. By the mid-1930s, however, the beauty editors of tabloid newspapers and weekly magazines had begun to endorse discreet making-up as a necessary technique of modern femininity. ${ }^{6}$ Caught between the lure of a fashionable modernity and the limits of local acceptance, women might experience a dilemma. For one Boots customer at least, the imagined solution lay in a paradoxical make-up both visible and invisible at the same time: an undetectable lipstick.

How should we interpret the timidity of this unknown Allenton woman, the subject of a brief anecdote in Boots in-house retail magazine, The Bee? Does her initial discomfort suggest a dawning era of aesthetic insecurity and consumerist compulsion, or did her final purchase mark a welcome entry into a pleasurable world of expressive self-creation? How, too, should we

Historical Journal of Film, Radio and Television, 26(4), pp. 461-84; Houlbrook, "The Man with the Powder Puff' in Interwar London.

${ }^{5}$ Judy Giles (1995) Women, Identity and Private Life in Britain, 1900-1950 (Basingstoke: Macmillan), p. 65; Catherine Horwood (2005) Keeping Up Appearances: Fashion and Class between the Wars, (Stroud: History Press), pp. 57-69; Janice Winship (2000) Culture of Restraint: the British Chain Store, 1920-39, in Peter Jackson, Michelle Lowe, Daniel Miller and Frank Mort (Eds.), Culture of Consumption: Economies, Practices, Spaces (Oxford: Berg), pp. $27-8$.

${ }^{6}$ Adrian Bingham (2004) Gender, Modernity, and the Popular Press in Inter-war Britain (Oxford: Clarendon Press), pp 173-6. Fiona Hackney (2010) "Natural" and "Unnatural" Types: Performing Modern Femininity through Cosmetic Practice and Display, in "They Opened Up a Whole New World": Feminine Modernity and the Feminine Imagination in Women's Magazines, 1919-1939 (unpublished PhD thesis, Goldsmith's College), pp. 213-256; Horwood, Keeping Up Appearances, p. 69. 
understand the experience of this unnamed shop assistant, required to expend some considerable emotional labour for what was clearly a disappointing sale? Feminist scholars have recently noted how political debates about beauty often become reductive battles between two analytical frameworks. ${ }^{7}$ Cosmetics are either critiqued for suturing women into patriarchal regimes of objectification, narcissism, triviality and expense, or else they are celebrated for sustaining sisterly cultures of agency and self-expression. Yet as Claire Colebrook has argued, both of these positions fall short when tested against the messy complexities of lived experience. "Feminist scholarship on beauty," she advocates, "has to proceed on a case-by-case basis" that remains empirically located and attentive to local intersectional specificities. ${ }^{8}$

The question for feminist politics, then, is not so much moral [...] but pragmatic: how is beauty defined, deployed, defended, subordinated, marketed, or manipulated, and how do these tactics intersect with gender and value? ${ }^{9}$

This article seeks to contribute to this project by exploring how one best-selling range of beauty preparations was presented and sold to middle-class women in mid-twentieth-century Britain. 'Number Seven' was launched by Boots the Chemists in May 1935, initially as a premium series of own-goods skin-care preparations. Whilst emulating the more exclusive 'beauty systems' of Helena Rubenstein and Elizabeth Arden, Number Seven's mass production brought it within the price range of ordinary middle-class women. ${ }^{10}$ Within twelve months, the

\footnotetext{
${ }^{7}$ Ana Elias, Rosalind Gill, and Christina Scharff (2017) Aesthetic Labour: Beauty Politics in Neoliberalism, in Ana Sofia Elias, Rosalind Gill, and Christina Scharff (Eds.) Aesthetic Labour: Rethinking Beauty Politics in Neoliberalism (London: Palgrave Macmillan), pp. 3-49; Rita Felski (2006) Because it is Beautiful: New Feminist Perspectives on Beauty, Feminist Theory, 7(2), pp. 273-282.

${ }^{8}$ Claire Colebrook (2006) Introduction, Feminist Theory, 7(2), p. 141.

${ }^{9}$ Colebrook, Introduction, p. 132.

${ }^{10}$ Lindsay Woodhead (2003) War Paint: Miss Elizabeth Arden and Madame Helena Rubenstein, Their Lies, Their Times, Their Rivalry (London: Virago); Geoffrey Jones (2010) Beauty
} 
range had become established and was freely available throughout Boots' nationwide network of over 1,100 stores, where it is still on sale today.

Number Seven is a useful historical case study because of its middle-brow positioning. Whilst not an object of either radical invention or elite high fashion, it nevertheless sought to temper these things and market them to suburban and provincial women. This produced some notable ambivalences around, for instance, its own mass production. Number Seven's provenance from Boots' new factory both lent the range an exciting modernity and reduced its cost, yet it also threatened to tarnish the brand with intimations of mass appeal. In practice, this was largely resolved by controlling how Number Seven was displayed in stores and attempts to codify how 'toilet assistants' interacted with their customers. In 1937, a second tension arose when Boots added the first colour cosmetics to the range. The company remained uncertain about the moral legitimacy of this new make-up, given its potential to disrupt or undermine middle-class standards of self-presentation and propriety. Even after the Second World War - a moment often used by historians to mark the full acceptance of make-up in Britain - Boots' advice to its female customers remained deeply anxious about the social meanings of lipstick and rouge. ${ }^{11}$

Imagined: A History of the Global Beauty Industry (Oxford: Oxford University Press), pp. 59-60, 103-4; Kathy Peiss (1998) Hope in a Jar: The Making of America's Beauty Culture (Philadelphia: University of Philadelphia Press), pp. 64-7, 73-5, 87-9.

${ }^{11}$ On the acceptance of make-up during wartime, see: Jones, Beauty Imagined, p. 136; Pat Kirkham (1995) Beauty and Duty: Keeping Up the (Home) Front, in Pat Kirkham and David Thoms (Eds.) War Culture: Social Change and Changing Experience in World War Two (London: Lawrence and Wishart), pp. 13-28; Janice Winship (1996) Women's Magazines: Times of Wear and Management of the Self in Woman's Own, in Christine Gledhill and Gillian Swanson (Eds.) Nationalising Femininity: Culture, Sexuality and British Cinema in the Second World War (Manchester: Manchester University Press), pp. 127-139. 
In addition, Number Seven's history across the mid-twentieth century reveals much about the cultural place of chain stores within British women's lives, a topic in receipt of surprisingly little academic attention. ${ }^{12}$ By the mid-1930s, chain stores or 'multiples' were prevalent on Britain's high streets and suburban arcades where they offered a more standardised, direct and impersonal way to shop. Their relative anonymity when compared to local traders made them key to the developing performance of middle-class femininity, particularly via displays of consumerist expertise which were now considered essential to professional housewifery. ${ }^{13}$ It is thus not surprising that in 1930, a woman in Allenton should have confided her anxieties about her own appearance to a toilet assistant in her local Boots, rather than to her next-door neighbour or her sister-in-law in London. Number Seven's commercial success was closely tied to these semi-scripted encounters, both within Boots stores and at off-site demonstrations. Tracing the historic shift in this relationship and its implication for women on both sides of the counter particularly after Number Seven was overhauled in 1952 - reveals close affinities between the commercial framing of beauty products and the terms through which women were able to operate within commercial public space.

\footnotetext{
${ }^{12}$ Pamela Cox (2017) Shop Girls, Social History and Social Theory, Revista Brasileira de Historia, 37(75), pp. 243-271. Available at: http://dx.doi.org/10.1590/1806-93472017v37n75-11. For excellent exceptions, see: Mica Nava (2000) Modernity Tamed? Women Shoppers and the Rationalization of Consumption in the Inter-War Period, in Maggie Andrews and Mary M. Talbot (Eds.) All the World and her Husband: Women in Twentieth-Century Consumer Culture (London: Cassell), pp. 46-64; Peter Scott and James T. Walker (2017) Large-Scale Retailing, Mass-Market Strategies and the Blurring of Class Demarcations in Interwar Britain, in Paolo di Martino, Andrew Popp and Peter Scott (Eds.) People, Places and Business Cultures: Essays in Honour of Francesca Carnevali (Woodbridge: Boydell Press), pp. 99-125; Winship, Culture of Restraint.

${ }^{13}$ Judy Giles (2007) Class, Gender and Domestic Consumption in Britain, 1920-1950, in Lydia Martens and Emma Casey (Eds.) Gender and Consumption: Domestic Cultures and the Commercialisation of Everyday Life (Abingdon: Ashgate), pp. 19-20; Nava, Modernity Tamed; Winship, Culture of Restraint, pp. 15-34.
} 
This article utilises the extensive holdings of the Boots Archive, a rich resource that has only recently become available to historians. ${ }^{14}$ It especially draws on the Merchandise Bulletin (a weekly circular sent out to all stores to inform them of new products and sales drives) and runs of various in-house magazines that were distributed to sales staff during different periods (The Bee, Sales and Selling, and Number Seven magazine). It also uses the Archive's guardbooks of Number Seven advertisements and its sizable museum collection of historic products. This material offers only limited insights into how Boots' customers used these beauty preparations in their everyday lives, how the products were experienced, and to what social effect. But it does reveal important cultural shifts, not only in the tone and texture of chain-store shopping, but in the wider formulation of facial beauty and its dynamic role in the imagining of modern women's lives.

\section{"The finest that science can produce": beauty in an age of mass production}

The feminine aesthetic originally propagated by Number Seven was closely tied to Boots' historic transformation into a modern industrial manufacturer. In 1920, Jesse Boot had sold the firm that he had largely run on autocratic lines to the United Drug Company of America. The new owners swiftly overhauled the company by installing the latest management techniques, restructuring the entire retail division, and building a huge manufacturing complex out at Beeston, a green-field site on the western edge of Nottingham. By 1933, when the firm returned to British ownership in the wake of the Wall Street Crash, Boots had already begun to co-

\footnotetext{
${ }^{14}$ In 2015, the Boots Archive received a Research Resources Award from the Wellcome Trust to catalogue its holdings. An on-line catalogue is now available at: www.archives.walgreensbootsalliance.com. The project is scheduled for completion in 2020.
} 
ordinate its production, distribution and retail processes. The efficient production lines of the D10 'Wets' factory at Beeston - a fiercely modernist building designed by the engineer Owen Williams - were increasingly integrated into a holistic approach that encompassed packaging design, the ordering of stock, window displays, and salesmanship at the counter. ${ }^{15}$ As staff were reminded in 1934: "Planned production, planned distribution and planned sales are the linked factors which will determine to a large degree the extent of our progress." 16

Boots' key objective during this period was to increase the sale of its 'own goods.' These generated greater profits than 'proprietaries' (products made by other manufacturers), avoided the recent imposition of resale price maintenance, and kept the new Beeston site safely in operation. ${ }^{17}$ In 1929, market research by J. Walter Thompson had discovered that respondents considered the relative cheapness of Boots' own goods to signify a corresponding lack of quality. ${ }^{18}$ In response, the company began a major publicity campaign to stress the scientific rigour of its manufacturing processes, and to fix Boots in the public mind as "The Nation's Toilet Specialists." ${ }^{\prime 19}$ Press advertisements offered vignettes from inside the factory, e.g. a whitecoated scientist looking down his microscope to measure the particles of face powder to $1 / 8000^{\text {th }}$

${ }^{15}$ J. E. Greenwood (1977) A Cap for Boots: An Autobiography (London: Hutchinson Benham), pp. 3-76; Paul Whysall (1997) Interwar Retain Rationalisation: Boots Under American Ownership', The International Review of Retail, Distribution and Consumer Research, 7(2), pp. $157-69$.

${ }^{16}$ H. J. Davis (Jan.-March 1934) Editorial, The Bee, 13(2), p. 47.

${ }^{17}$ Peter Scott and James T. Walker (2017) Retailing Under Resale Price Maintenance: Economies of Scale and Scope, and Firm Strategic Response, in the Inter-war British Retail Pharmacy Sector, Business History, published online 21 June.

${ }^{18}$ Research Department of J. Walter Thompson Company (Sept. 1929) Report of Investigation: Boot's Cash Chemist, Men and Women, United Kingdom [WBA/BT/11/17/2/5].

${ }^{19}$ Edward Richardson (Nov. 1930) Science and Cosmetics, The Bee, 10(1), pp. 23-6; Anon. (April-May 1931) We Tell the World the Facts: Our New Advertising Campaign, The Bee, 10(6), p. 182. 
of an inch. ${ }^{20}$ In many ways, the launch of Number Seven was the culmination of this campaign. Originating within "Boots world famous Research Laboratories," these were, the company proclaimed, "the finest [preparations] that science can produce for beauty's needs." ${ }^{21}$ As an integrated scientific beauty system, rather than an arbitrary collection of unrelated products, Number Seven helped to reinforced Boots' public image as a modern manufacturer, even as the modernism of the new Beeston factory appeared to guarantee the range's corporeal effects.

In the early 1930s, Boots had also experimented with series-selling as a strategy for increasing both sales and prestige. In 1932, the firm had taken a number of well-established, but unrelated own goods, rebranded them as the 'De Luxe' range, and repackaged them in the same geometric bottle. ${ }^{22}$ The expectation was that a customer loyal to one particular product would now be prompted to try out the rest, encouraged by the eye-catching in-store displays that the uniform bottles made possible. ${ }^{23}$ Number Seven reiterated this commercial approach, whilst deploying the discourse of physiological science to give it a greater legitimacy. "The first sale [of a Number Seven product] is the sale of an idea," counter staff were told in 1936. "Once the idea is sold, the items in the series naturally sell in numbers." 24

Geoffrey Jones has observed that all manufacturers of skin-care products face the same endemic challenge. Unlike colour cosmetics, skin preparations produce no immediate visible

20 'FACTS that mean more BEAUTY for you when you use Toilet Preparations from BOOTS' (14 Sept. 1932) Daily Mail, p. 16.

${ }^{21}$ Beauty Without Extravagance (1938), advertisement for Number Seven [WBA/BT/11/45/1/1/19].

${ }^{22}$ Edward Richardson (June 1932) The Truth about the De Luxe Series, The Bee, 11(4), pp. 1578.

${ }^{23}$ Edward Richardson (Jan.-March 1934) Modern Packaging Design, The Bee, 13(2), p. 86.

${ }^{24}$ Anon. (9 March 1936) No. 7 - a Popular Number, Merchandise Bulletin, 472, p. 4619

[WBA/BT/11/38/1/1/13]. 
change and are thus much harder to market to consumers. ${ }^{25}$ In order to promote Number Seven, Boots turned to the same rhetoric of industrial efficiency that was then being used to promote the wider company. This was, the advertisements announced, "the MODERN way to LOVELINESS," as the logics of Fordist mass production were used to remodel female beautification and articulate its physiological impact on the skin. ${ }^{26}$ The skin-care process was broken down into a set of component tasks, each of which was expertly accomplished by a particular product in the range. To ensure their maximum productivity, these were then to be performed in the full correct order. For instance, a woman of 'normal' skin-type had to begin by refreshing her face with Number Seven Skin Tonic (mixed with a little cold water), then cleanse it using Number Seven Cleansing Cream, then tone it using Number Seven Skin Tonic, then protect it with Number Seven Foundation Cream, and finally to lightly dust it with Number Seven Face Powder. ${ }^{27}$ The efficacy of each component product within the Number Seven system thus depended on its place within a calculated sequence that mimicked the structure of the industrial process through which it had been made.

This Fordist logic meant that Number Seven could easily be inserted into wider inter-war narratives of consumer democracy and progressive social change. At the range's launch, held in Boots' flagship store on Regent Street on 1 May 1935, journalists were handed a statement that compared Number Seven to such other modern wonders as the motor coach, the wireless, and ready-to-wear clothing. Each of these inventions had made "amenities $[\ldots]$ which in previous generations were confined to the well-to-do and privileged classes" suddenly available to

\footnotetext{
${ }^{25}$ Jones, Beauty Imagined, pp. 62-3.

26 ...Announcing the MODERN Way to LOVELINESS (1935), advertisement [WBA/BT/11/45/1/1/].

${ }^{27}$ Beauty (1935), Number Seven customer advice booklet, p. 6 [WBA/BT/11/40/4/1/7].
} 
ordinary women. ${ }^{28}$ By aligning itself with the dawning age of mass production, Number Seven like the new electrical appliances of the servantless home, or the semi-self-service of chain-store shopping - was framed as an encounter with modernity itself. ${ }^{29}$ "Every woman her own beauty expert," the advertisements proclaimed, positioning Number Seven as a key point of entry into a modern femininity built on technical competency and professional know-how. ${ }^{30}$

Yet if every woman now expertly managed the technical production of her own facial beauty, then she was also, by default, her own assembly-line worker, compelled to repeat a monotonous set of regulated tasks. "Number 7' stands for more than mere creams and lotions," sales staff were told in 1937. "Beauty is not acquired simply by applying Beauty preparations. The technique of application is very important. [...] Preparations and method of treatment are inseparable. ${ }^{31}$ From the range's inception, customers were given a free advice booklet called 'Beauty' that instructed them in meticulous detail on how to apply these products correctly. This, for instance, was how a woman was to tone her skin:

Make a simple patter by folding a piece of Cotton Wool to make a firm pad about six inches long and two inches wide. Soak it in cold water and squeeze out. Twist

\footnotetext{
${ }^{28}$ Press statement distributed at the launch of the Regent Street Beauty Parlour, 1 May 1935, reprinted in The Bee (April-May 1935), 14(3), p. 116.

${ }^{29}$ Maggie Andrews (2012) Domesticating the Airwaves: Broadcasting, Domesticity and Femininity (London: Continuum), pp. 30-54; Bingham, Gender, Modernity and the Popular Press, pp. 84-110; Sue Bowden and Avril Offer (1996) The Technological Revolution that Never Was: Gender, Class and the Diffusion of Household Appliances in Interwar England, in Victoria de Grazia and Ellen Furlough (Eds.) The Sex of Things: Gender and Consumption in Historical Perspective (Berkeley: University of California Press), pp. 244-274; Judy Giles (2005) Good Housekeeping: Professionalising the Housewife, 1920-1960, in Krista Cowman and Louise A. Jackson (Eds.) Women and Work Culture: Britain c. 1850-1950 (London: Routledge), pp. 70-86; Penny Tinckler and Cheryl Krasnick Warsh (2008) Feminine Modernity in Interwar Britain and North America: Corsets, Cars, and Cigarettes, Journal of Women's History, 20(3), pp. 113-143. ${ }^{30}$ Every Woman Her Own Beauty Expert (1938), advertisement for Number Seven [Y371/108].

${ }^{31}$ Now... the Full Story of Number Seven (Oct. 1937), supplement to Merchandise Bulletin, unpaginated [WBA/BT/11/38/1/1/21].
} 
sufficient of one end to make it convenient for holding, and dip the other end in 'Number Seven' Skin Tonic. ${ }^{32}$

To apply the pad correctly, women were then choreographed through a tight sequence of patting motions:

Follow the lines round the throat and neck, avoiding the centre of the throat; from the centre of the chin, following the contour of the face, cover any suggestion of a laughing line from chin to nose, and pat the brow with upward and outward movements. On no account pat the centre of the cheeks or the temples.

Finally, wipe the face with a tissue. ${ }^{33}$

Importantly, this procedure had to be followed every day. "REMEMBER - The secret of success in Beauty Culture lies in the REGULARITY of the Treatment," customers were told. "A few minutes EVERY night and morning is the golden rule." ${ }^{34}$ Echoing the procedures of scientific management set out by Frederick Taylor, a set of written instructions was meant to transmute with daily repetition into an habitual dexterity - which also perpetuated personal usage of the Number Seven range. ${ }^{35}$

These prescriptions found an acute incarnation in the Number Seven Beauty Boxes, a set of luxurious, portable cases that already came filled with a selection of products. The smallest box, which was sold complete at 12/6, contained "the bare minimum for a week-end visit in the smallest possible space": Cleansing Cream, Skin Tonic, Foundation Cream and Face Powder,

\footnotetext{
${ }^{32}$ Beauty (1937), Number Seven customer advice booklet, p. 8 [WBA/BT/11/40/4/1/1].

${ }^{33}$ Beauty (1937), p. 9. Emphasis in the original.

${ }^{34}$ Beauty (1937), p. 13.

${ }^{35}$ Frederick Winslow Taylor ([1911/1998) The Principles of Scientific Management (Mineola: Dover), esp. p. 64.
} 
plus cotton wool with which to apply them. ${ }^{36}$ On the Boots toilet counter, the Beauty Boxes reinforced the democratic modernity of Number Seven by embedding it within an aspirational narrative of motorised leisure travel. Yet they also reinforced the range's Fordist imperatives, since to miss a single weekend's applications was now seen to jeopardise one's hard-won facial beauty. Furthermore, by framing its contents as an holistic set, the Beauty Box encouraged women to buy replacement products each time they were confronted by an unsightly gap. ${ }^{37}$

In practice, the diligent labour of this domestic regime was obscured by Boot's management of an in-store service culture that clearly intimated notions of class mobility and prestige. Central to this was the Boots Beauty Parlour, which opened on the second floor of the Regent Street branch on the day of Number Seven's launch. The Parlour sought to emulate the luxury salons clustered around nearby Bond Street, whilst tempering that elite experience for a popular chain store on one of London's busiest thoroughfares. From a smart central waiting area, decorated with pastel-pink walls and a striking green carpet, women were led off into one of four private treatment rooms. Here a trained assistant took the customer through a sequence of Number Seven applications personalised to suit her own skin type and colouring, whilst also administering a facial massage. The cubicles themselves were "designed to provide the utmost possible comfort and hygiene" - in reality, an awkward mix of colonial domesticity (reclining wicker chairs) and clinical sophistication (newly invented angle-poise lamps). ${ }^{38}$ Customers could purchase a course of twelve treatments for $£ 3 / 13 / 6$, but the appearance on the pricelist of a halfhour 'Special Short Treatment' at only 3/6 suggests that the Parlour was primarily conceived as a

${ }^{36}$ Anon. (12 July 1937) "Number 7" Improvement, Merchandise Bulletin, 536, p. 5286 [WBA/BT/11/38/1/1/21].

${ }^{37}$ Anon. (9 May 1938) "No 7” Cases, Merchandise Bulletin, 575, p. 5718 [WBA/BT/11/38/1/1/22].

38 'Sylvia' (April-May 1935) A Wonder Beauty Parlour, The Bee, 14(3), p. 115. 
treat for out-of-town shoppers. ${ }^{39}$ By 1937 , toilet assistants at any Boots branch could give their customer an invitation card for a free Short Treatment if they knew her to be visiting London or any of the other four cities in which, by then, a Beauty Parlour had been opened. ${ }^{40}$

The Boots Beauty Parlours were a highly useful marketing tool. "The mere fact 'as used exclusively in our Beauty Parlours,' is sufficient to put a hall-mark on 'Number 7' preparations," its assistants were told. ${ }^{41}$ The Regent Street salon gave the range a second imagined epicentre alongside that of the Beeston works, which guaranteed its efficacy less through the rigors of scientific manufacture than a proven record of customer satisfaction. It anchored Number Seven's nationwide distribution in the same way that Arden's and Rubenstein's West End salons supported their own firms' concession stands in up-market provincial department stores. Yet on a more practical level, the Beauty Parlours also served as customer training rooms for the rituals of self-service skin-care. "[A]dvice given by an expert in the atmosphere of the salon is very acceptable," the company claimed, "and is long remembered,"42 If instruction was embedded within a prestigious experience, a customer was more likely to follow it at home.

In large towns without a Beauty Parlour, Boots organised public events in the tea rooms of prominent hotels. These were hosted by Mrs W. G. Dalrymple, employed by the firm as a Beauty Consultant to help develop its feminine product lines, and were heavily advertised in the local press. At Number Seven tea parties, expert demonstrators showed the assembled

\footnotetext{
39 This Way, Madam, to London's Latest Beauty Salon (1935), advertisement for Boots Beauty Parlour [Y371/112].

${ }^{40}$ Anon. (22 Nov. 1937), Free Treatments, Merchandise Bulletin, 555, p. 5502

[WBA/BT/11/38/1/1/21]. The second Boots Beauty Parlour was opened in the Manchester Royal Exchange store in 1936. In 1937, a final three were opened in Cambridge, Cardiff, and the Birmingham New Street stores.

${ }^{41}$ Now... the Full Story of Number Seven, unpaginated.

${ }^{42}$ Free Treatments, p. 5502.
} 
townswomen how to apply its various creams and lotions, before they took up residency in the town's main store for a period of personal consultation. ${ }^{43}$ By taking customer training out of the shop with its atmosphere of overt salesmanship, the tea parties remodelled it as a select society event. Venues like the Queen's Hotel in Southsea or the Saracen's Head Hotel in Lincoln were imbued with a modern sense of democratic mobility, even as they remained relatively oldfashioned and secure in their prestige. Like Number Seven itself, they combined a formal inclusivity with an air of exclusive privilege.

Most women, of course, only encountered Number Seven at the toilet counter of their local Boots store. Here, to preserve its credibility as a scientific system, Boots insisted that all assistants who sold the range displayed an advanced level of product expertise. In 1935, a Staff Training Room was opened at the Beeston site, at which selected sales staff from across the country received a week of practical instruction (Figure 1). In The Bee, 'Jadette', a fictional everywoman toilet assistant, reported on the thrills of learning the correct applications:

We heard all about the No. 7 Preparations, and were told by Miss Cunningham that we were going to use them ourselves several times during the week. Isn't it lovely to have all those jars and bottles in front of you to use as you like - or rather to use as they ought to be used. [...] Everyone had a mirror and a full set of No. 7 preparations, and I fairly itched to get at them. I half expected that Miss Cunningham would sort of say 'Go', and we could just wallow in them. But, oh dear, no. We had to do it properly, and what a time we had. ${ }^{44}$

\footnotetext{
${ }^{43}$ Now... the Full Story of Number Seven, unpaginated.

${ }^{44}$ Jadette Goes to Nottingham (May 1936), supplement to The Bee, unpaginated [WBA/BT/11/38/1/1/19]. Emphasis in the original.
} 
Upon returning to their home branch, Beeston alumnae were asked to share their new expertise with in-store colleagues. Yet as Number Seven became more established, the demand for staff training soon outstripped supply. Alternative provisions were put in place and by 1937, hundreds of assistants from London's smaller branches had received their training instead during a single free treatment at the Boots Beauty Parlour on Regent Street. ${ }^{45}$

The campaign to promote Boots as a scientific manufacturer put these toilet assistants in a complicated relationship to their female clientele. They had to play a dual role - at once authoritative expert and commanded servant - that required careful negotiation at the counter: When next serving [a customer] with face powder, shampoos or other toilet preparations, make some comment about the particular feature of the article purchased. That should give you an opening to utter some little tip as regards its use, or to contrast it with a similar article that may be of interest. Your conversation should be informative, designed to let the customer see that you have a skilled knowledge. Sooner or later that customer will be seeking your advice - if you have suitably impressed her. ${ }^{46}$

The key was to remain deferent whilst embarking on a determined form of technical pedagogy. Yet for the specific sale of Number Seven, a second contradiction also had to be negotiated. Whilst the range's mass production and chain-store distribution made it modern, accessible, and more affordable to women, Boots already sold many other versions of the same

\footnotetext{
${ }^{45}$ Anon. (27 July 1936) "Beginning at Home", Merchandise Bulletin, 491, p. 4852 [WBA/BT/11/38/1/1/19].

${ }^{46}$ Sumus (May-July 1934), Balancing Up, The Bee, 13(4), p. 187.
} 
generic products, as both proprietaries and own goods, at considerably cheaper prices ${ }^{47}$ How, then, to present the Number Seven range in a way that justified the additional expense?

In the early 1930s, Boots' embrace of modern salesmanship had explored the lucrative aesthetics of mass consumption. Well-planned displays of the same amassed commodity were found to create connotations of proven popularity, economy of scale, and the freshness of product that only came with a fast turnover of stock. ${ }^{48}$ Waist-high counter trays had proved particularly useful since they invited customers to handle the products, something that was seen to create a somatic bond that might expedite the sale. ${ }^{49}$ By contrast, however, Number Seven was only to be displayed "in keeping with the high class nature of the products." ${ }^{\text {50 }}$ There were to be no accumulated piles and it was strictly forbidden to extricate an item and display it alongside other versions of the same generic product. ${ }^{51}$ To preserve its integrity as a holistic system, Number Seven could only to be exhibited as a complete range. "This series should always be given a 'de luxe' setting," assistants were told. "'Number 7' calls for imagination in showing a few articles, but putting a luxury atmosphere round them." ${ }^{52}$ The suggestion was to artfully arrange two of three samples of each product surrounded by well-chosen props from elsewhere in the store. This display was then be segregated from the rest of the stock by a stand or a

\footnotetext{
${ }^{47}$ For instance, Number Seven Face Powder cost three shillings, whilst large boxes of Leichner and Tokalon cost 2 shillings and 1/6, respectively. Anon. (6 June 1935) Toilet 'Props', Merchandise Bulletin, 435, p. 4246 [WBA/BT/11/38/1/1/13].

48 J. H. Stretton (Nov-Dec 1932) Modern Salesmanship: Its ABC, The Bee, 12(1), pp. 19-20; Sumus (March 1936) Silent Salesmanship, The Bee, 15(2), pp. 91-2; Anon. (27 Sept. 1937) Mass Displays, Merchandise Bulletin, 5389, p. 5390 [WBA/BT/11/38/1/1/21].

${ }^{49}$ Sumus (June 1932) Making Buying Easy, The Bee, 11(4), p. 173.

${ }^{50}$ Anon. (13 Jan. 1936) Number Seven, Merchandise Bulletin, 463, p. 4535 [WBA/BT/11/38/1/1/13].

${ }^{51}$ Anon. (3 May 1937) Series Displays, Merchandise Bulletin, 526, p. 5178; Anon. (11 Oct. 1937) 'To Be Alone', Merchandise Bulletin, 549, p. 5422 [WBA/BT/11/38/1/1/21].

${ }^{52}$ Series Displays, p. 5178.
} 
framing glass plate (Figure 2). This technique discouraged the customer from handling the goods herself, as did the highly modern use of cellophane wrappers that created an aura of unsullied purity. ${ }^{53}$ Together these presentational mechanisms recentred the expert toilet assistant as the necessary mediator between customer and product. Thus even as Number Seven was extending the principle of customer self-service onto the domestic dressing table, it rejected the techniques of chain-store merchandising for the theatricality of the exclusive department store.

\section{The ontology of 'loveliness'}

The logic of mass production did not only structure accounts of Number Seven's physiological efficacy. It was also the base for a particularly modern conception of facial beauty. In its early customer advice booklets, the female face was imagined as analogous to an industrial apparatus which the expert woman now had to manage and maintain for herself. Above all, loveliness was dependent on a constant, steady movement and unhindered flows. The circulation of blood had to be kept vigorous and the pores unblocked of any accreted "waste matter." Like the workforce of any modern factory, "at night the skin relaxes, because the circulation tends to become sluggish and the surface muscles are tired." A deep cleanse and some good evening nourishment allowed the skin to recuperate overnight, before it was briskly "revivified" in the morning, ready for another day's productive beauty. ${ }^{54}$ The second edition of the 'Beauty' booklet

\footnotetext{
53 Anon. (11 Oct. 1937) Perfection, Merchandise Bulletin, 549, p. 5422 [WBA/BT/11/38/1/1/21]; Stephen Gundle (2008) Glamour: A History (Oxford: Oxford University Press), pp. 250-1. Ironically, these cellophane wrappers, which gave the impression that Number Seven products were untouched by human hands, were applied manually by female workers in the packing room at Beeston.

${ }^{54}$ Beauty (1935), pp. 3-5.
} 
featured a particularly telling diagram to illustrate the movements a woman's fingers ought to make when applying her Number Seven face creams (Figure 3). Whilst the white arrows prescribed the direction of digital force around the features, the overall effect was to map the face as a dynamic territory or as an organised system of flows. The royal-blue background and reductive lines provided an almost literal blueprint for an efficient modern beauty that was strongly reminiscent of an engineer's design for the internal processes of a factory.

As the final product to which all this was directed, the notion of 'loveliness' requires further interrogation. As might be expected for a scientific skin-care system, promotional material for Number Seven repeatedly equated facial beauty with a soft and smooth complexion. Every woman could become 'lovely' if she bought the right sequence of preparations, learned to apply them correctly, and unfailingly adhered to her daily routine. Loveliness was thus a democratic form of beauty in contrast to more elitist models based on breeding or physiognomic luck. Its accessible notion of improvement for all - rooted in a combination of self-discipline and modern expertise - particularly accorded with the unadorned aesthetic being promoted by the contemporary physical culture movement. ${ }^{55}$ In 1937, the Women's League of Health and Beauty, the largest interwar female keep-fit organisation, boasted 120,000 members across 220 branches. ${ }^{56}$ This nationwide coverage paralleled Boots' own network of chain-store chemists, and its core membership of office workers and young married housewives overlapped considerably with Number Seven's target demographic. Upon joining the League, each member

\footnotetext{
${ }^{55}$ Charlotte Macdonald (2013) Body and Self: Learning to be Modern in 1920s-1930s Britain, Women's History Review, 22(2), pp. 267-279; Jill Julius Matthews (1990) They Had Such a Lot of Fun: The Women's League of Health and Beauty Between the Wars, History Workshop Journal, 30(1), pp. 22-54; Ina Zweiniger-Bargielowska (2010) Managing the Body: Beauty, Health and Fitness in Britain, 1880-1939 (Oxford: Oxford University Press), pp. 236-278. ${ }^{56}$ Macdonald, Body and Self, p. 272.
} 
had to pledge to spend fifteen minutes a day on "practical health-building in the body." might involve attending an exercise class, playing a team sport, or walking in the open air; but it might also take the form of choreographed exercises "designed to give the maximum results in the minimum of time" at home. ${ }^{58}$ Number Seven's own domestic rituals were similarly framed as a type of keep-fit for the face, its rhetoric slipping easily from that of industrial efficiency into that of physical culture. Skin Food prevented "relaxed muscles and flabbiness", Astringent Lotion repaired "drooping muscles", and the euphemistically named Muscle Oil ("a penetrating and easily absorbed vegetable oil, very delicately perfumed") was "invaluable if the skin is drawn and requires building up." ${ }^{59}$ Women were told to administer these products using swift, gentle movements "with two middle fingers of one hand, working upwards and outwards" across the face. ${ }^{60}$ These small digital exertions against gravity took on the symbolic import of an exercise regime in miniature. If practised each day and with due care and attention, the face would gain the same radiant glow as the healthy, energetic female body.

Number Seven's notion of facial loveliness also shared the keep-fit movement's residual, class-bound conservatism. ${ }^{61}$ In equating a clear and bright complexion with "real" feminine beauty, Number Seven reiterated a longer tradition of moral investments in white translucent skin. ${ }^{62}$ In the second half of the eighteenth century, the cult of sensibility had positioned women's cheeks as a privileged site for the display of feminine virtue. The act of blushing,

${ }^{57}$ Beauty [magazine of the Women's League of Health and Beauty] (June 1933), 1(1), p. 1, cited in Matthews, They Had Such a Lot of Fun, p. 26.

${ }^{58}$ Mary Bagot Stack (1933) Building the Body Beautiful: The Bagot Stack Stretch-and-Swing System (London: Chapman and Hall), p. 3, cited in Matthews, They Had Such a Lot of Fun, p. 26.

${ }^{59}$ Beauty (1935), p. 20; Beauty (1937), p. 16-17.

${ }^{60}$ Beauty (1935), p. 22.

${ }^{61}$ Matthews, They Had Such a Lot of Fun, pp. 48-49.

${ }^{62}$ No. 7: Loveliness That Outlasts the Years (1938), advertisement [WBA/BT/11/45/1/1/4]. 
generally understood as involuntary, became a physiognomic marker of a woman's modesty and a test of her moral sentiment. ${ }^{63}$ According to this model, the female face was a veracious window onto the soul - a construction that naturalised the social privilege of middle-class white women, whose skin was unsullied by industrial toil, the tanning of farm-work or the grime of the city's streets. The use of any artificial colourant became framed in relief as an act of inherent deception, the immoral practice of common prostitutes and other corrupted women that falsely laid claim to an absent virtue that their souls could not produce. ${ }^{64}$

In the early twentieth-century, this physiognomic reading was progressively challenged, first by the use of make-up among fashionable metropolitan elites, and then by the take up of mass-produced cosmetics by younger working-class women. By the mid-1930s, rouge, lipstick, and even eye shadow were increasingly visible on Britain's streets and shop counters, but makeup could still be read as pretentious and sexualised, especially on the faces of adolescent factory girls. J. B. Priestley, for instance, sitting in a cinema café in Boston, Lincolnshire in 1933, noted with a mixture of fascination and concern the altered faces of the "imitation Greta Garbos" seated at adjacent tables. ${ }^{65}$ Certainly for any middle-class housewife secure in her status and marital circumstance, such naked displays of romantic aspiration were not befitting. Indeed,

\footnotetext{
${ }^{63}$ Maggie Angeloglou (1970) A History of Make-Up (London: Studio Vista), pp. 96-98; W. Ray Crozier and Peter J. de Jong (2013) The Study of the Blush: Darwin and After, in W. Ray Crozier and Peter J. de Jong (Eds.) The Psychological Significance of the Blush (Cambridge: Cambridge University Press), pp. 1-11; Angela Rosenthal (2004) Visceral Culture: Blushing and the Legibility of Whiteness in Eighteenth-Century British Portraiture, Art History, 27(4), pp. 563-592; Taeko Sakai (2013) Redi-no Sekimen: Vikutoriacyo Shakai to Kesyo Bunka (Tokyo: Keiso Shobo).

${ }^{64}$ Fenja Gunn (1973) The Artificial Face: A History of Cosmetics (Newton Abbott: David and Charles), pp. 126-140; Madelaine Marsh (2014) Compacts and Cosmetics: Beauty from Victorian Times to the Present Day (Barnsley: Pen and Sword History), pp. 17-22. See also: Peiss, Hope in a Jar, pp. 9-36.

65 J. B. Priestley (1934) English Journey (London: William Heinemann Ltd), p. 377.
} 
Boots' in-house magazines often sought to preserve the company's distance from those cheaper brands of proprietary make-up on which it made a profit. Justifying its "considerable" sale of Rimmel lipsticks at only sixpence apiece, the firm declared: "Although we do not make a point of featuring 6d. Lipsticks, you know that a large number are sold, and we must get our share of this business. ${ }^{966}$ Boots even made its own brand of sixpenny lipsticks called Lareine, although tellingly "Boots" didn't appear on its in-store showcards. As late as October 1936, the Merchandise Bulletin still critiqued the "rather too liberal use of lipsticks and rouges" by women in the United States “as judged by English tastes", even as Max Factor and other American brands were becoming the company's best-sellers. ${ }^{67}$ "Romance is in the air...," assistants were told in 1937:

Film Stars...

Glamorous Beauties...

Hollywood.

To our lady customers, Max Factor is romance.

Smile if you will, but the fact remains that our customers are definitely interested in Max Factor - and their interests are ours. ${ }^{68}$

Number Seven's middle-class customers were protected from such pejorative associations, firstly, by its construction as strictly a skin-care system and, secondly, by those instore display mechanisms that avoided any intimation of mass appeal. Yet paradoxically, for all

\footnotetext{
${ }^{66}$ Anon. (14 March 1938) Rimmel's Lipstick, 6d., Merchandise Bulletin, 567, p. 5638 [WBA/BT/11/38/1/1/22].

${ }^{67}$ Anon. (19 Oct. 1936) Cosmetics and Cleansing, Merchandise Bulletin, 502, p. 4948 [WBA/BT/11/38/1/1/19].

${ }^{68}$ Anon. (26 July 1937) Max Factor, Merchandise Bulletin, 538, p. 5317

[WBA/BT/11/38/1/1/21]. My emphasis.
} 
Boots' residual antipathy towards Hollywood glamour, the company found it hard to avoid when producing imagery for its flagship range. Early magazine advertisements for Number Seven used photography rather than illustration, a modern medium whose indexical fidelity suited the company's wider claims to technicity and truth. To take a typical example from 1938 (Figure 4): a model's face is shown tightly cropped against a dark, neutral background; the main light source (here, from a low oblique angle) is countered by a softer fill light to correct the shadows, and another downward light-source that highlights her hair. This was the three-point lighting system invented in Hollywood before the First World War and soon established as the best configuration for presenting actresses' faces on screen. As Richard Dyer notes, it made white skin look at its most luminescent, placing the Hollywood close-up within a longer history of idealised representations of effulgent white femininity. ${ }^{69}$ It is thus not surprising that when Boots sought to visualise an explicitly modern form of facial loveliness, it borrowed heavily from the conventions of cinema.

As contemporary critics were quick to note, the cinematic close-up abstracted an actress's face from its contextual narrative and presented it on-screen as a wondrous object for the audience to simply behold. ${ }^{70}$ Number Seven's photography did much the same thing; whilst the adjacent copy discussed the range's provenance and the biological importance of feeding the skin tissues, the radiant face appeared alongside as an autonomous, self-evident fact. According to the logic of Number Seven skin-care, loveliness was an ontological state, a property of each and every female face that was diligently maintained by the correct scientific system. This was,

\footnotetext{
${ }^{69}$ Richard Dyer (1997) White (London: Routledge), esp. pp. 86-103.

${ }^{70}$ Bela Balazs (1952) Theory of the Film (Character and Growth of a New Art), trans. Edith Bone (London: Denis Dobson, Ltd), p. 61; Jean Epstein (1977) Magnification and Other Writings, trans. Stuart Liebman, October, 3, pp. 9-25. See Mary Ann Doane (2003) The CloseUp: Scale and Detail in Cinema, Differences, 14(3), pp. 89-110.
} 
then, a tautologous form of beauty. It existed outside of any feedback loop and didn't depend on the appreciation of others. Like an actress's face in cinematic close-up, it projected forth its own anticipated audience - as happy to play to an empty auditorium as a packed house full of admirers. Indeed, the 'Beauty' booklet repeatedly described the face as if it was a cinema screen. A beautiful skin didn't sag or betray slackness, but remained tight on its skeletal frame. It was smooth, flawless and freckle-free. "Tired skin is freshened and blemishes disappear," customers were promised; "contours that sagged are braced again to their original lovely lines."71 Number Seven Astringent would restore the skin's "natural elasticity," before Number Seven Foundation Lotion would impart an "impalpable, even bloom" that "form[ed] a perfect base for powder."72 This culminating application of face powder was especially significant. It was the crucial last stage in the beautification process, important enough to make Number Seven Face Powder one of the four essential preparations in the 12/6 Beauty Box. For Richard Dyer, face powder was an endemically ideological product because it made white skin look matte; in combatting the shine caused by reflected light, it maintained the impression that a woman's face glowed virtuously from within. ${ }^{73}$ Yet its widespread ubiquity in 1930s Britain locates it as a key technology of transition. Whilst, following Dyer, powder reiterated the traditional morality of the clear and clean complexion, it paradoxically created a new opacity that worked to preclude properly translucent skin. This clearly registered the cultural force of the cinematic close-up. Powdered cheeks were ineffective as a window onto the soul; instead, they turned the face into a non-translucent screen, a receptive surface awaiting the projection of shifting, ephemeral

${ }^{71}$ The Modern Way to Loveliness (c.1937), Number Seven customer sales leaflet, unpaginated [WBA/BT/11/40/4/1/2].

${ }_{72}^{72}$ Beauty (1935), p. 23, p. 26.

${ }^{73}$ Dyer, White, p. 122. 
fantasies. They marked, in effect, the tentative acceptance of a more modern ontology of facial beauty rooted in a transitory play of surfaces.

In practice, Number Seven's investment in the radiant complexion already involved a tentative acceptance of make-up, for the luminosity of its models' white skin required an emphatic visual contrast to darkly coloured lips. ${ }^{74}$ Indeed, within a year of Number Seven's launch, Boots' executive Formula Committee had already revised their intention to "restrict this series absolutely to health and beauty preparations" by deciding to add a Cream Rouge and even a "high quality Lip Stick" to the range. ${ }^{75}$ Their motivation was almost certainly commercial. From the mid-1930s, the successful British launch of such mid-market American brands as Tattoo, Jane Seymour, and (especially) Max Factor had encouraged a greater middle-class acceptance of colour cosmetics, particularly through their extensive and sophisticated advertising campaigns. All these products were available from Boots, which threatened sales of the company's own goods. ${ }^{76}$ "There is keen competition in the 'lipstick world'," the firm noted in 1938. "Each manufacturer is trying to go one better than his competitor."

The all-male Formula Committee consulted Boots' toilet assistants for advice on which make-up to develop. The tabulated replies show huge favour for a lipstick, a block mascara, and a rouge in both cream and compact form. ${ }^{78}$ After Mrs Dalrymple and the Number Seven

\footnotetext{
${ }^{74}$ See Hackney, "They Opened Up a Whole New World."

75 No. 7 Beauty Series, Formula Committee Minutes, 6 May 1936, p. 6007 [WBA/BT/9/4/1/21].

${ }^{76}$ Anon. (13 June 1935) "Tattoo" Lip Stick: The Very Latest from New York, Merchandise Bulletin, 436, p. 4262 [WBA/BT/11/38/1/1/13]; Anon. (14 April 1936) Max Factor Beauty Preparations Arrive in England, Merchandise Bulletin, 476, p. 4684 [WBA/BT/11/38/1/1/19]; Anon. (9 Aug. 1937) Jane Seymour Beauty Preparations, Merchandise Bulletin, 540, p. 5337 [WBA/BT/11/38/1/1/20].

${ }^{77}$ Anon. (11 April 1938) Jane Seymour Beauty Preparations, Merchandise Bulletin, 571, p. 5683 [WBA/BT/11/38/1/1/22].

${ }^{78}$ Formula Committee Minutes, 19 August 1936 [WBA/BT/9/4/1/21].
} 
demonstrators had tested the prototypes, the Number Seven "Cosmetiques" appeared in stores in October 1937. There were five of them in all: a Rouge Compacte, a Rouge Cream, and a Lipstick (all of which came in the same five shades); an Eye Shadow in a plastic pot; and a block of Eyelash Cosmetique (mascara) in its own chromium case. Significantly, however, the new edition of the 'Beauty' booklet published to coincide with the make-up's launch failed to even mention its existence. Instead the sole focus was on scientific skin-care, now seen to depend on "the whole process of living; a correct diet, a normal amount of suitable exercise, adequate rest, the care of internal conditions, and personal hygiene," as well as the twice-daily application of Number Seven preparations. ${ }^{79}$ The booklet's most explicit discussion of colour came in its opening paragraph:

The secret of the preservation of natural Beauty lies in something more vital than colourful adornment, or the hiding of blemishes by a heavy covering of cosmetics. Blemishes which may have been regarded as permanent can be treated in other ways than by hiding them, and those which are incidental will yield to treatment without waiting for their disappearance with the passage of time. ${ }^{80}$

The series was thus introduced through a traditional opposition between the virtuous discipline of sanative skin-care and the deceptive excess of make-up. This was, in effect, also the difference between the respectable restraint of middle-class femininity and the gaudiness of working-class girls.

Such anxieties continued throughout the Second World War. In April 1940, five months before the government imposed restrictions on the industrial production of cosmetics, the

\footnotetext{
${ }^{79}$ Beauty (1937), p. 1.

${ }^{80}$ Ibid., p. 1.
} 
Formula Committee noted that unlike "practically every other manufacturer," Boots had failed to create a lipstick shade to match the military colours of khaki and blue. ${ }^{81}$ Possibly in response, new advertisements for Number Seven began to appear in the women's monthlies that eschewed monochrome photography for colourful and expressive line drawings. Each one centred on a woman engaged in a different wartime occupation, although their languid poses suggested a comfortable distance from manual toil. The central message - that life in uniform need not come and the cost of one's feminine appearance - was a dominant trope of wartime beauty discourse and found keen expression in the sketches' elongated eyelashes and lipstick-reddened pouts. Yet the adjacent copy stayed tightly focussed on the importance of skin-care and avoided all discussion of colour cosmetics:

The scene has changed from Mayfair to the muddy fields of the shires. The smart frock has given place to the breeches and leggings of the Land Army. Yet, despite rough work and exposure to all weathers, her loveliness remains unmarred. For care of beauty is neither costly nor troublesome with Number Seven preparations. Made perfect by more than fifty years of Boots' experience, they are as effective in the rustic billet as they were in the well-appointed boudoir. ${ }^{82}$

At a time of crisis and limited means, women tended to favour the quick fix of make-up over the hard-won benefits of a radiant complexion. These advertisements might therefore have been designed to boost sales of skin-care preparations at a commercially difficult time. Yet their concern about the meanings of colour cosmetics persisted even after Number Seven fully returned to the toilet counter in 1949. A new version of the customer booklet (which went by the

${ }^{81}$ Lipsticks, Formula Committee Minutes, 2 April 1940 [WBA/BT/28/49/1/4].

${ }^{82}$ Fresh Fields for Beauty... (March 1940), advertisement for Number Seven [WBA/BT/28/49/1/4]. 
original slogan of "The Modern Way to Loveliness") remained nervous about the deceptive potential of the make-up products it now explicitly promoted. "Loveliness is akin to Nature," women were reminded in its frontispiece:

Many women make the mistake of spending time and money on make-up, while neglecting the three basic rules of skin care - CLEANSE, TONE and NOURISH. Makeup can never camouflage a neglected skin. ${ }^{83}$

This twice-daily ritual remained sacrosanct, for "the beauty of your skin should glow from within." ${ }^{\circ 4}$ Only after this had been achieved could "the skilful, restrained use of cosmetics" add a final touch of elegance, rather than serve to conceal or disguise. ${ }^{85}$ The sanctioned result was for "a naturally made-up face: rouge, very sparingly used; powder, even; eye-shadow, only the merest hint." 86 This was the same anxiety about visible cosmetics that had troubled a Boots customer in Allerton nearly two decades before. In 1950, a correct make-up was still one that proffered "just a suspicion of eye-shadow"; applications of rouge should be "almost imperceptible"; and the virtuous qualities of Number Seven's lipstick lay in its discreet "stay-on texture." 87

\section{"The Time to be Lovely is - Always": situational beauty and post-war public femininity}

\footnotetext{
${ }^{83}$ The Modern Way to Loveliness (c. 1950), Number Seven customer advice booklet, unpaginated [WBA/BT/11/40/4/1/12].

${ }^{84}$ Ibid., unpaginated.

${ }^{85}$ Ibid., unpaginated.

${ }^{86}$ Ibid., unpaginated. Emphasis in the original.

${ }^{87}$ Ibid., unpaginated.
} 
During the late 1940s, the keen competition in the lipstick world that Boots first noted in 1938 returned to Britain with a vengeance. The impact of UK manufacturers returning to full production was intensified by American firms' aggressive attempts to infiltrate the British market. ${ }^{88}$ Within the pages of women's magazines, expanded ranges of colour cosmetics competed to promote their own fashionability, innovation and choice, a backdrop against which Number Seven's reticence about make-up seemed increasingly outmoded. In response, Boots decided to give its flagship brand a comprehensive relaunch. To revive its fortunes, the company turned to Phyllis Digby Morton, previously an editor of Woman and Beauty magazine, a regular contributor to the BBC's Woman's Hour and a member of the Ministry of Information's wartime advisory committee on women's morale. Digby Morton was, Boots noted, “an acknowledged authority on every aspect of personal charm and feminine taste and psychology," and was thus a suitable figurehead to guide the company through its repositioning of Number Seven. ${ }^{89}$ On 15 May 1952, the new range appeared in the shops. The products now came in honey-and-gold plastic containers designed to appear both elegant and luxurious, but neutral enough to match the colour scheme of any woman's bedroom or bathroom. ${ }^{90}$ The make-up shades were also revised and given more evocative names; for instance, Blue Eye Shadow became Blue Mist, whilst Garnet Rouge Cream became Glowing Garnet Cream Rouge.

Of greatest significance was the dramatic tonal shift in Number Seven's advertisements. The philosophy behind the new approach was explained to staff as follows:

\footnotetext{
${ }^{88}$ Angeloglou, A History of Make-Up, pp. 128-131; Gunn, The Artificial Face, pp. 161-166; Jones, Beauty Imagined, pp. 151-60; Peiss, Hope in a Jar, pp. 245-9.

${ }^{89}$ Anon. (Spring 1952) Selling Beauty - With Confidence, Number Seven, p. 1 [WBA/BT/11/34/2/2/11].

${ }^{90}$ Phyllis Digby Morton, in ibid. p. 2.
} 
The Number Seven Story is the story of you and me and women like us saleswomen, secretaries, young married women, and 'teenagers'. [...] In each advertisement a real woman speaks - there is a photograph of her in her 'everyday' dress telling us her story and how the 'NEW, better, and lovelier' Number Seven beauty preparations solved her complexion problems.

And since she, like all of us, has to work most of the day, and her problems are our problems, all the women who read the advertisement will feel:

"This is real. This is like me. This is something worth trying." $" 1$

Whilst this new realism partly echoed Number Seven's parade of military women managing to maintain their loveliness, it also chimed with post-war women's general desire to remain in paid employment. In 1951, 35\% of British women had jobs of whom $43 \%$ were married, and these percentages would continue to rise throughout the following decade. ${ }^{92} \mathrm{By}$ 1952, Boots had already identified working women as its most lucrative demographic for beauty products. Market research had found salaried women to be much more willing to spend money on cosmetics than those financially dependent on their husbands. Young working women were a particular target, since 16 to 19 -year-olds spent a hefty eight shillings per month on beauty preparations and make-up. ${ }^{93}$

Yet the "real woman" in her "everyday" dress" represented a major revision in Number Seven's articulation of feminine beauty. By tying their advertisements to individual archetypes

${ }^{91}$ A. N. Other Woman (Spring 1952) The Number Seven Story, Number Seven, p. 5. Emphasis in the original.

${ }^{92}$ Penny Summerfield (1996) The Girl that Makes the Thing that Drills the Hole that Holds the Spring...: Discourses of Women and Work in the Second World War, in Gledhill and Swanson (Eds.) Nationalising Femininity, p. 49. See also Helen McCarthy (2017) Women, Marriage and Paid Word in Post-war Britain, Women's History Review, 26(1), pp. 46-61.

${ }^{93}$ Anon. (Spring 1952) Are Women Beauty Conscious?, Number Seven, p. 11. 
and their associated beauty problems, loveliness was reframed as reactive and contextual. It became intimately tied to real-life situations and the successful negotiation of social demands. In contrast to the 1930s, beauty was no longer presented as an essential state, sustained by the discipline of scientific skin-care. Instead, it had become tactical, rooted in responses to everyday activities and the consequent appreciation of real - rather than merely anticipated - others. One of the earliest new advertisements featured a photograph of 20-year-old model Joan Burgess sat smilingly in front of her typewriter at work (Figure 5). Under the headline "He looks at me a hundred times a day!", the text laid out the beauty dilemmas of an upwardly-mobile office worker:

In my job - secretary to an important executive - looks help, of course, but they aren't everything. Still, knowing I'm well-groomed all day does give me extra confidence. Appearance counts when you want promotion. So I was thrilled to discover the Number Seven Cream Foundation; it holds my powder through the busiest day and it's not expensive; that's the amazing thing. I found, too, that the Perfect Pink lipstick is indeed perfect for my colouring $!^{94}$

If this advertisement recognised the greater opportunities for women in the burgeoning post-war office economy, it also made clear that a key professional competency was the ability to constitute oneself as the object of a man's gaze. This was heavily coded in terms of class. As Gillian Murray has noted, the private secretary became an icon of post-war modernity for the manifold administrative and emotional skills that rendered her the perfect 'office wife'. Unlike her lesser-trained colleagues in the promiscuous typing pool, the secretary's dedication to a

\footnotetext{
94 'He Looks at Me a Hundred Times a Day!' (1952), advertisement for Number Seven [WBA/BT/11/34/2/2/2].
} 
single boss extended the normative practices of middle-class housewifery into the domain of paid employment. ${ }^{95}$ The emotional labour of companionate marriage easily crossed over into the workplace (and visa versa), which included the perpetual management of one's appearance for the visual pleasure of one's husband/boss.

During the 1950s, advertisements for Number Seven consistently promoted the need to look good as a condition of entering public life. Women no longer appeared as mute and spectacular objects that existed outside of all contextual narratives. Instead they were seen to do a wide range of everyday activities, which only underscored the situational nature of post-war beauty and its dependence on the conferral of men and other women. Loveliness, in itself, was no longer guaranteed by the routine application of the correct creams and lotions. It was now something to attend to throughout the day, as individual women circulated through different public spaces and adjusted thier appearance to the requirements of each. Advertisements stressed the compartmentalisation of modern women's lives. One example from 1953 used composite images of the same model doing three different tasks: reading the mail in her housecoat; standing on the street making a date in her diary; and attending a function in a ballgown and evening gloves (Figure 6). "Whatever she does... she does it beautifully", ran the headline; "what can make her happier than knowing she is lovely to look at, whatever she is doing?"

Since post-war beauty was perceived to exist within a feedback loop, it was now perpetually threatened by the possibility of its own collapse. As an advertisement warned in 1956: "Travelling, walking, cycling, dancing, someone is always looking at you. Your beauty

${ }^{95}$ Gillian Murray (2017) Taking Work Home: The Private Secretary and Domestic Identities in the Long 1950s, Women's History Review, 26(1), pp. 62-76; see also Claire Langhamer (2017) Feelings, Women and Work in the Long 1950s, Women's History Review, 26(1), pp. 86-7. 
can never take time off. Be sure it never fails you." ${ }^{96}$ This strategic use of make-up to dispel feelings of anxiety had been a familiar experience to many during the Second World War, as good grooming had become both a military requirement and a psychological support. Many women had gained strength from putting on their brave face every morning - an outward (and inward) show of defiance and a welcome reassurance that life still went on. ${ }^{97}$ Post-war beauty discourse demilitarised this psychodynamic and extended its emotional labours into peacetime. As Number Seven's secretary made clear in 1952, knowing that one looked presentable was the key to maintaining "confidence," or the knowledge that one's current audience believed in the reality of the role one was playing.

This conceptual shift altered the imagined function of beauty products themselves. Their physiological effects on the pores and facial muscles became less important than their social utility as adaptive equipment. The linear, sequential beauty system was eclipsed by a more modular understanding, based on choosing the right items, as and when they were needed. Whilst the foundational skin-care regime remained important, Number Seven was increasing promoted using the same logic as the casual separates that were becoming ascendant within ready-to-wear clothing, i.e., as an expansive selection of coordinated items, which could be combined and recombined to suit different situations. As the decade wore on, the range spawned ever more products and became increasingly portable. In 1956, for instance, Boots launched Number Seven Beauty Soap, Number Seven Talcum Powder and Number Seven Soap Leaves. The latter was a stapled book of paper sheets impregnated with soap; specifically designed to be

\footnotetext{
${ }^{96}$ Someone is Always Looking at You (1956), advertisement for Number Seven [3253/17].

${ }^{97}$ Kirkham, Beauty and Duty; Kirkham (1996) Fashioning the Feminine: Dress, Appearance and Femininity in Wartime Britain, in Gledhill and Swanson (Eds.) Nationalising Femininity, pp. 152-174; Winship, Women's Magazines, pp. 137-139.
} 
carried in the handbag, it enabled a woman to clean her face wherever she found a tap. The following year saw the advent of Number Seven Satin Hair Spray - a huge best-seller, especially when issued in a portable 'handbag size' can - and Number Seven Bath Salts. By the early 1960s, stoked by both the steady rise in women's wages and the expansion of urban leisure opportunities, Number Seven had left the dressing table and the temporal confines of its twicedaily ritual. Disseminated throughout quotidian space and time, it also lost its presentational integrity in store. Boots dropped the rule that Number Seven could only be displayed holistically, separately and in full. For instance, staff were encouraged to exhibit Number Seven Soap Leaves everywhere in the shop that other soaps were displayed ("Show them where they sell!"). ${ }^{98}$

Throughout the 1950s, Number Seven's customer booklets gave only scant advice on make-up. Women were merely told to choose the shades that flattered their clothing and colouring (but not on what basis to determine that flattery), and to match up their lipstick to their rouge. Yet this was less symptomatic of Boots' earlier reticence, than of the perception that its customers were now fully immersed in the proliferate beauty culture of women's magazines. The company saw such editorial as a challenge to the authority of its toilet assistants, whose advice was now less likely to be requested or adhered to:

We realise you are dealing with people who think they know a great deal about creams and cosmetics. Your customers have a different attitude when they go over to the Chemist's counter where they are more likely to defer to the technical knowledge of pharmacists and dispensers. But there is a lot your customers do not

\footnotetext{
${ }^{98}$ Anon. (3 Feb. 1958), Number Seven Soap Leaves, The Bulletin, 550, p. 1-2 [WBA/BT/11/38/1/3/27].
} 
know, and a wise and sympathetic approach will convince many of them that it is worth talking to you about beauty preparations. ${ }^{99}$

The challenge was "to prove that you are not merely agents through whom the public are able to obtain the things they have read about in magazines and advertisements," and thus to establish their own toilet counter as the "place where there is more knowledge and experience about beauty problems than anywhere else in your town." 100

To help disseminate this knowledge to its assistants, Boots produced Number Seven, a new biannual in-house magazine that informed staff in a casual tone of the latest trends in clothes and make-up. Phyllis Digby Morton (who was also the wife of the couturier Henry Digby Morton) gave seasonal reports from the Paris and London catwalks, with special attention to prominent colours and the Number Seven shades that would complement them. "Mary Severn" (the pseudonym of Miss Davies who ran the Staff Training School at Beeston) advised on such presentational problems as "Should I use eye shadow?" and "How can I freshen up between the office and a date?"101 Assistants were taught how to coordinate a lipstick to an outfit, which foundations suited particular complexions, and what shades of powder worked best under artificial lights. But as the definition of counter expertise shifted from physiological knowledge to presentational tips, the assistants' own cosmetic experience gained a new economic premium. Their role became increasingly that of a friendly mentor, whose main qualification was the visible proficiency of her own skills of self-presentation. As sales assistants were reminded in 1956:

\footnotetext{
${ }^{99}$ Anon. (Spring 1952) A Message from the Sower, Number Seven, p. 12. Emphasis in the original.

100 Ibid., p. 12.

${ }^{101}$ Mary Severn (Spring 1954) Mary Severn's Skin Care Quiz, Number Seven, p. 15 [WBA/BT/11/34/2/2/11].
} 
You're always being looked at behind your counter, and you yourself are a living, walking advertisement for the NUMBER SEVEN beauty preparations you sell. It's your pleasant job to help make other women more "lookable-at", to show them how NUMBER SEVEN can make them look their best always. ${ }^{102}$

This implied commonality - if never quite equality - between sales assistants and customers was strengthened in 1954 by an increase in the staff discount on Number Seven products to $3 \mathrm{~d}$. in the shilling, which brought the range down to within toilet assistants' budgets. ${ }^{103}$ To feed this sense of cross-counter empathy, Number Seven profiled a succession of modern career girls. who each described the pleasures and challenges of her job and the causes and solutions of its attendant beauty problems. Women like Vera McKechnie (a Guest Announcer on BBC television) and Pam Tilburn (a hostess at London Airport) were presented both as potential customers who might ask for an assistant's advice and as compatriots within the post-war world of commercial feminine display. ${ }^{104}$ Assistants were reminded that their job was not only to consult and to sell, but also to perform for their in-store audience ("the full spotlight is on you as surely as on any actress standing in the middle of a stage"), and that their willingness to experiment with the latest make-up trends would increase their utility to women like themselves. ${ }^{105}$ Through their own emotional and aesthetic labour as confident public women,

${ }^{102}$ Anon. (Spring 1956) Someone is Always Looking at You..., Number Seven, p. 6 [WBA/BT/11/34/2/2/11]. Emphasis in the original.

${ }^{103}$ S. Harker-Smith (Autumn 1954) Foreword, Number Seven, p. 2 [WBA/BT/11/34/2/2/11].

104 Anon. (Spring 1957) The Girl on Your TV Screen, Number Seven, pp. 10-11

[WBA/BT/11/34/2/2/11]; Anon. (Autumn 1957) Hostess... to a Hundred Guests a Day, Number Seven, pp. 10-11 [WBA/BT/11/34/2/2/11].

${ }^{105}$ Phyllis Digby Morton (Autumn 1953) Beauty Begins Behind the Counter, Number Seven, p. 4 [WBA/BT/11/34/2/2/11], emphasis in the original; Phyllis Digby Morton (Spring 1954) The New Look in Beauty, Number Seven, p. 4. 
they both defined and demonstrated the efficacy of Number Seven products, and thus inspired other women to trust in its effects.

During the 1950s, Boots stores became the site for increasingly public performances of beauty. In 1957, the first Number Seven Beauty Bar was opened in the flagship Regent Street branch, at which customers learned to make themselves up under the guidance of trained demonstrators. ${ }^{106}$ Yet unlike the private beauty treatments that had been administered there before the war, these self-service applications occurred under the gaze of other shoppers. By the end of the decade, many of the firm's major city-centre stores had hosted 'Festivals of Beauty' that were similarly centred on self-application, and which often led to participating customers making brief appearances on the local television news. ${ }^{107}$

It seems fitting, then, that in September 1959, the first prize in Cheltenham's annual Battle of Britain Carnival Day parade should have been won by a float entitled 'Seven Ages of Beauty' (Figure 7). Devised and constructed by local Boots staff, this static tableau featured seven women dressed to embody the beauty ideals of different historical periods, from the Stone Age, past the Elizabethan Age, and on to the Edwardian Age. Last of all came assistant Maureen Spear in a simple floral dress: 'Number Seven: The Beauty of Today. ${ }^{\text {'108 }}$ As Zoe Thomas has recently explored, women's organisations of the 1920s and '30s had frequently produced historical pageants to articulate a feminist heritage of national service and citizenship. ${ }^{109}$ The Boots float clearly spoke to this tradition, but co-opted the format for a post-war celebration of

106 Anon. (Autumn 1957) Beauty is her Business, Number Seven, p. 4.

107 Anon. (Sept. 1959) Spring Festival of Beauty, Sales and Selling, 29, pp. 12-13

[WBA/BT/11/38/1/4/36]; Anon. (Oct. 1961) Number Seven Festival of Beauty, Sales and Selling, 37, pp. 7-8 [WBA/BT/11/38/1/4/44].

108 C. G. Whitehead (March 1960) Seven Ages of Beauty, The Bee, 31(1), p. 42.

109 Zoe Thomas (2017) Historical Pageants, Citizenship, and the Performance of Women's History before Second-Wave Feminism, Twentieth Century British History, 28(3), pp. 319-343. 
chain-store beauty culture. Read diachronically, the seven women's fancy dress told a progressive story of democratisation, from the aristocratic lady of the Medieval Age to the 1950s everywoman in her ready-to-wear frock. But read synchronically, these seven women in the same modern make-up also created a sisterly image of collective self-expression. Heading the parade as it wove its way through Cheltenham, watched from the pavement by many friends and local customers, these Boots assistants on the back of a truck asserted the right of ordinary women like themselves to centrally inhabit public space. Yet they also dramatized the network of surveillance that accompanied this new status in post-war Britain, and the need to maintain an appropriate beauty for those who had come to look.

\section{Conclusion}

In the spring of 1957, Boots updated the Number Seven advice booklet and gave it a brand new title: "NOW... is the Time to Look Lovely." Whilst at first glance, this name seems fairly coterminous with "The MODERN Way to LOVELINESS" (the brand's original slogan from May 1935), the small semantic shift from being lovely to looking lovely marked a major revision in the social conception of middle-class feminine beauty. Before the war, loveliness had been sold as an ontological state, an essential property of any female face that was scientifically managed by the properly administered techniques. By the second half of the 1950s, this notion had become outmoded, replaced by a responsive, situational understanding of beauty, premised on social networks of expectation and appraisal.

In its earlier construction, "loveliness" was the site of a complex transition between older moral investments in the virtuous good complexion and a modern understanding of the female 
face as a receptive screen for fantasy. Advertisements in Vogue during May 1935, the month of Number Seven's launch, reveals just how central loveliness was to interwar notions of bourgeois beauty: "the secret of breath-taking loveliness lies in the petal-smooth-skin"; "makes you lovely, clearing and refining your skin so that it becomes soft as silk"; "Go back to Nature for natural loveliness." ${ }^{110}$ Persistently linked to skin-care products rather than to coloured make-up, loveliness continued the ideological celebration of radiant white skin, but in a way that could accommodate subtle augmentations and the opacity of powder.

By May 1957, this commercial rhetoric had changed: "Let it keep you looking fresh and lovely always!"; "Stays colour-bright and beautiful, hour after hour... no 'guilty' trace on cups, cigarettes - or people!”; "Would her face tell you her age? [...] Look younger, fresher lovelier." ${ }^{111}$ Men - a significant absence from beauty advertisements in the 1930s - now frequently appeared, to semantically fix the female face as an object of scrutiny and appreciation. ${ }^{112}$ In 1950 s beauty discourse, middle-class women's greater entry into public life was thus accompanied an imperative towards perpetual aesthetic self-maintenance, whilst the Fordist logic of sequential skin-care was superseded by the modular tactics of adaptive make-up.

\footnotetext{
${ }^{110}$ What is the Secret of Growing Lovelier? (15 May 1935), advertisement for Innoxa Lovelifying Treatment, Vogue, p. 20; All You Need is an Elizabeth Arden Treatment (29 May 1935), advertisement, Vogue, p. 117; Back to Nature...for Natural Loveliness (29 May 1935), advertisement for Marguerite Hoare beauty preparations, Vogue, p. 133. My emphasis for all. ${ }^{111}$ Night and Day... this is the One! (May 1957), advertisement for Revlon's Love-Pat foundation, Vogue, p. 78; 'Coral Touch' by Peggy Sage (May 1957), advertisement, Vogue, p. 153; Would Her Face Tell You Her Age? (May 1957), advertisement for Endocil hormone cream, Vogue, p. 199. My emphasis for all.

112 With a Touch of Magic... (May 1957), advertisement for Yardley's Pink Magic lipstick, Vogue, p. 135; To Put Stars in Your Eyes (May 1957), advertisement for Max Factor, Vogue, p. 189; Would Her Face Tell You her Age?, p. 199; Easy Steps to Flawless Beauty (May 1957), advertisement for Leichner's Kamera Klear Base, Vogue, p. 200.
} 
Of course, even before the Second World War, women's use of cosmetics had required an acute sensitivity to contingent social context. For many women in Allerton and elsewhere, to apply one's make-up was always to negotiate the unstable signifiers of class, respectability, modernity and desire. To this extent, the mid-century transition from the reified abstractions of cinematic loveliness to the grounded demand to always look lovely revealed a growing realism in the promotion of cosmetics that ran much deeper than its stylised pictures of secretaries and housewives. That everyday desire to appear both respectable and modern endemically required the navigation of this tension, long before it found its belated expression within the post-war call to confidence. 


\section{Acknowledgement:}

This research was originally carried out in preparation for Inspiring Beauty: No7 - Eighty Years of Making Up the Modern Woman, an exhibition that ran at Lakeside Arts Centre's Weston Gallery in Nottingham from January to April 2016. This exhibition was a collaboration between myself, Judith Wright and Sophie Clapp of the Boots Archive, and the University of Nottingham's Manuscripts and Special Collections. I wish to express my enormous gratitude to both Judith and Sophie, in particular. Many of the ideas within this article developed as a result of our conversations and Judith's encyclopaedic knowledge of the history of No7 proved an invaluable resource. 
Figure 1: Toilet Assistants applying face powder in the new Staff Training Room at Boots' headquarters in Beeston. Taken from: The Bee, 14(3), April-May 1935, p. 126. The Boots Archive.

Figure 2: Suggested counter display for the Number Seven range. Taken from: Anon. (11 Jan. 1946) Number Seven, Merchandise Bulletin, 463, p. 4535. The Boots Archive [WBA/BT/11/38/1/1/13].

Figure 3: Diagram indicating the correct motions for applying Number Seven face creams. Taken from: Beauty (1937), Number Seven customer advice booklet, p.11. The Boots Archive [WBA/BT/11/40/4/1/1].

Figure 4: The Modern Way to Loveliness (1938), magazine advertisement. The Boots Archive [Y310/4].

Figure 5: He Looks at Me a Hundred Times a Day! (1952), magazine advertisement. The Boots Archive [WBA/BT/11/34/2/2/2].

Figure 6: Whatever She Does... She Does It Beautifully (1953), magazine advertisement. The Boots Archive [WBA/BT/11/34/2/2/1].

Figure 7: 'Seven Ages of Beauty', the winning float in Cheltenham's Battle of Britain Carnival Day parade, September 1959. Taken from: The Bee, 31(1), March 1960, p. 1. The Boots Archive. 